\title{
Online Learning During the Covid-19 Pandemic: Reflection on Self- Efficacy of Primary School Teachers in Teaching Online
}

\author{
Esa Nur Wahyuni ${ }^{1 *}$, Retno Mangestuti², Iffat Maimunah ${ }^{3}$, Rahmat Aziz ${ }^{4}$ \\ ${ }^{1}$ Fakultas Tarbiyah \& IImu Kependidikan UIN Maulana Malik Ibrahim Malang, Indonesia \\ 2,4 Fakultas Psikologi UIN Maulana Malik Ibrahim Malang, Indonesia \\ ${ }^{3}$ Fakultas Ekonomi UIN Maulana Malik Ibrahim Malang, Indonesia \\ *e-mail: esanw@uin-malang.ac.id¹, mangestuti@uin-malang.ac.id², iffatmaimunah@uin-malang.ac.id ${ }^{3}$, \\ azira@uin-malang.ac.id ${ }^{4}$
}

\begin{abstract}
One of the critical variables in the online learning process during the Covid-19 pandemic is teachers' self-efficacy to their ability to carry out online learning. However, the fact is not all teachers have the efficacy of teaching online. The article invites readers to reflect by analyzing the causes of low selfefficacy of elementary school teachers carrying out online learning. The study used a mixed-method approach involving 22 elementary school teachers. Primary and secondary data collection using questionnaires, interviews, observations, and documentation. Data analysis used quantitative and qualitative. The results show that three factors cause low self-efficacy of elementary school teachers: first, teachers' perception that online learning is ineffective and efficient; second, weak mastery and skills to apply technology for learning; and thirdly, the lack of online learning support facilities during the pandemic. This study's results can be an empiric basis for improving teachers' quality by schools, communities, and governments, especially related to online learning, not only during the Covid-19 pandemic but also in the long run education in the digital age.
\end{abstract}

Keywords: Online Learning, Self-Efficacy, Verbal Persuasion

\section{Introduction}

Online learning system in the pandemic covid has been considered an intelligent solution for the learning process that maintains social distancing rules. Hopefully, this system can resolve sustainability in the education areas and health at once. Nevertheless, in practice, online learning presents many problems and challenges, especially for teachers (Joshi et al., 2020; Kayabınar et al., 2021; Mardiana, 2020; Rachmadtullah \& Samsudin, 2020). Teaching from home means minimal digital skills are required, technology facilities for teachers and students (Cardullo et al., 2021; El Refae et al., 2021). More vital character discipline, adaptability, psychological flexibility, creativity, innovation, critical thinking, and self-efficacy are required (Santi et al., 2020). Teachers are challenged not only to be able to deliver lesson materials but also to provide more excellent guidance and assistance and integrate online resources to organize learning content, create high-quality online learning environments, and emphasize learning process management to stimulate students' learning motivation and improve learning effects (Baber, 2020; Ma et al., 2015).

Successful online learning depends on the teacher's ability to maintain students' learning motivation, structure learning, prepare students to learn in a virtual space (Karasmanaki \& Tsantopoulos, 2021; Richardson \& Newby, 2010). Phenomena in the field, not all teachers are ready because all challenges in learning must be faced in unstable psychological conditions, influenced by forced isolation, anxiety against invisible dangers, stress, and panic (Dhawan, 2020). The unprepared situation triggered teachers' low selfefficacy to teach online (Uzunboylu \& Ozdamli, 2011). The self-efficacy of weak teacher causes a lack of confidence to achieve learning goals, as a result of which the teacher does not achieve well-being in his work, feeling stressed, anxious, and helpless (Hensley, 2014; Wang et al., 2015).

\section{${ }^{*}$ Corresponding author.}

Received March 22, 2021; Accepted May 10, 2021; Available online December 25, 2021 This is an open access article under the CC BY-SA license. Copyright $(2021$ by Author. Published by Universitas Pendidikan Ganesha 
The research results showed a big difference between face-to-face learning and virtually reviewed learning from quality assurance and characteristics of the learning experience (Singh \& Thurman, 2019; Wargadinata et al., 2020). In the context of these differences, testing, analyzing, and understanding research related to teacher self-efficacy is highly relevant (Corry \& Stella, 2018). A teacher's self-efficacy is a measure of a teacher's belief that they can influence student success. In traditional face-to-face classes, student learning and growth are closely correlated with teacher self-efficacy (Alibakhshi et al., 2020; Amin et al., 2021). As long as student achievement succeeds at the heart of every education system, research on teacher self-efficacy is of interest for educators and researchers.

In general, self-efficacy refers to self-confidence in regulating and taking the necessary actions to achieve the expected goals (Hong et al., 2015; Liao et al., 2018). Selfefficacy is also different from self-concept, which refers to a person's general self-perception formed through experience and interpretation of his environment (Marsh et al., 2019; Sharma \& Srivastava, 2020). Self-efficacy is future-oriented what can do or what can be achieved (descriptive). In comparison, self-concept is based on past achievements and evaluation of what has been done. Thus, it can be asserted that self-efficacy is more descriptive, while self-concept is more descriptive and evaluative (Berga et al., 2021; Lazarides et al., 2020).

Based on the concept of self-efficacy Bandura, then teacher self-efficacy can be defined as assessing a person's ability to achieve the desired results of teaching activities even when facing various obstacles and when students are not motivated (Lazarides et al., 2020). Teachers with high efficacy will be more open to new learning ideas and methods, more constructive in dealing with student problems, and resilient to difficulties (Alibakhshi et al., 2020; Cornelia et al., 2019). Teacher self-efficacy is a theoretical construction in the context of teaching, formed by the teacher's characteristics (gender, teaching experience), class characteristics (grade level, student performance), and school characteristics (principal). Teacher self-efficacy is not a character brought by the teacher since he was born, but rather the result of the interaction of the teacher's personality, behavior, and environment (Cornelia et al., 2019; Putri \& Fakhruddiana, 2019; Sharma \& Srivastava, 2020). At least four teacher self-efficacy sources: mastery experience, vicarious, verbal persuasion, and somatic and affective states.

The extent to which the mastery experience increases self-efficacy depends on various factors such as the perception of own abilities, perceived task difficulties, amount of effort, and external support (Lazarides \& Warner, 2020; Skaalvik \& Skaalvik, 2010). Suppose the teacher does not have a mastery experience before facing a new and challenging situation. In that case, the teacher will rely on observation (and comparing himself to others who are similar) to others' activities that positively affect the vicarious experience. However, it can also be self-modeling teachers, i.e., teachers make observations of themselves, such as observing their teaching behavior in the classroom via video). Observing the behavior of self-teaching performance can also increase self-efficacy (Hampton et al., 2020; Sa'pang \& Purbojo, 2020).

The third source of self-efficacy is verbal persuasion, i.e., a statement or notice to the teacher to overcome a particular problem. Verbal persuasion has limited effects of improving teacher self-efficacy and helps individuals increase more significant effort to successfully overcome difficulties to reduce the impact of self-doubt (Lazarides \& Warner, 2020). Selfefficacy beliefs built from verbal persuasion will only sustain the teacher's self-efficacy for a while if there is no further effort. Therefore, mentoring or training teachers who lack experience will build teacher self-efficacy (Cornelia et al., 2019; Sökmen, 2021). The last source of self-efficacy is a physiological and affective state. This source is also referred to as self-efficacy building emotional stimulation (Marsh et al., 2019; Yang et al., 2020). The physiological and emotional state of the teacher while performing the task. Positive feelings such as enthusiasm and confidence can strengthen self-efficacy, while negative emotions such as anxiety and fatigue decrease self-efficacy, as they show individuals are not prepared to achieve goals and face challenges.

Based on existing empirical studies, more broadly, self-efficacy is significant for students' and teachers' learning process. Self-efficacy teaching can lead to psychological 
well-being in teachers, including teacher job satisfaction, personal achievement, and fulfillment of commitments (Moè et al., 2010; Türkoğlu et al., 2017; Zee \& Koomen, 2016), and negatively correlated with the saturation of teaching (Tzioti et al., 2010). As for students, self-efficacy teaching teachers can improve motivation and achievement, academic adjustment, and student welfare (Achurra, 2012; Clayson \& Sheffet, 2012). In other words, teacher self-efficacy affects teacher professionalism in teaching and determines student success (Alibakhshi et al., 2020). However, self-efficacy is a personal character that exists in teachers and determines the direction of online learning success during the pandemic, the study of why self-efficacy of primary school teachers is limited.

In the context of online learning in primary schools, studies on teacher self-efficacy are more likely to be focused on two things, first reviewing teacher self-efficacy as a variable that influences online learning success (Yang et al., 2020). Second, self-efficacy widely studied as a phenomenon of teacher conditions that arise during online learning (Fauzi \& Sastra Khusuma, 2020; Haverback, 2020). Studies that reflect low self-efficacy teachers are still rare. This study aimed to complete the analysis of elementary school teachers' selfefficacy towards online learning. This paper examines explicitly why the primary school teachers' self-efficacy is low. At least three factors are assumed to be the cause of teacher self-efficacy: (1) teacher perception or confidence in the efficiency and effectiveness of online learning, (2) the digital competencies that teachers have, and (3) support of online learning systems. The analysis of these three factors allows for a holistic understanding of the teacher's efficacy of online learning. This paper is based on the argument that teacher selfefficacy is an essential variable for online learning success. Low teacher efficacy will impact the poor quality of online learning and teachers' and students' inability to learn.

\section{Method}

This study explains the relationship between online learning and teacher self-efficacy through a mixed-methods approach by collecting primary and secondary data. Primary data was collected through questionnaires, interviews, and observations about online teaching teachers' readiness, teacher perception of, online teaching experience, the experience of attending online learning training or education, and support of online learning facilities and systems. At the same time, secondary data was collected through documentation of teacher competency development programs in schools and teacher backgrounds. Both types of data were chosen as the basis for analyzing and reflecting on the common antecedents of selfefficacy elementary school teachers teaching online during the covid 19 pandemic.

This study involved 22 elementary school teachers in Tlekung village in Batu city as participants. The 22 teachers are participants in pedagogy competency improvement training for online learning. The interviews with teachers and principals knew that the 22 teachers experienced difficulties and anxiety of teaching online. Demographic data showed that elementary school teachers as participants have a working period of between 2 - 35 years. Participants' ages ranged from $29-59$ years. With a bachelor's degree

Table 1. Demographic Characteristic of Participants

\begin{tabular}{ccc}
\hline Variable & Description & Number \\
\hline Certification & Undergraduate & 22 \\
Gender & Male & 8 \\
& Female & 14 \\
Age & $25-40$ & 11 \\
& $41-50$ & 6 \\
Teaching experience & $51-60$ & 5 \\
& $1-5$ years & 2 \\
& $6-10$ years & 3 \\
& $11-15$ years & 7 \\
& $16-20$ years & 2 \\
\hline
\end{tabular}




\begin{tabular}{ccc}
\hline Variable & Description & Number \\
\hline $21-25$ years & 3 \\
& $26-30$ & 2 \\
& $31-35$ & 3 \\
\hline
\end{tabular}

The research instrument used is a questionnaire given directly to the participants. The questionnaire contains (1) how teachers perceive online learning (efficiency, effectiveness, results), (2) mastery skills and application of technology in online learning, (3) online learning training that followed and its impact on the implementation of learning, (4) how to achieve learning objectives with online learning, (5) the problems of online learning during the pandemic, (6) how emotional conditions, in general, are related to online learning. Data collection is also conducted by interviewing teachers formally and informally during the training activities as a follow-up of questionnaire data collected.

Data analysis carried out through stages, first separating quantitative and qualitative data. Second, quantitative data had analyzed with descriptive statistics. Third, qualitative data is read over and over again and understood by researchers. Fourth, performed open and axial coding. The fifth after coding complete, then the data is analyzed through a focus group discussion (FGD) involving researchers and experts in the relevant field to extract the data. Fifth, the extract results are further verified to the participants to ensure the correctness and clarity of the data obtained.

\section{Result and Discussion}

\section{Results}

Online learning by utilizing mobile technology is the foremost choice and cannot be denied. One of the essential variables in the online learning process is teacher motivation and self-efficacy in implementing online learning. However, the facts show that not all teachers have the confidence to carry out online teaching. This study's results reveal at least three reasons for teachers' low self-efficacy in online teaching: first, teachers' perceptions of less efficient and effective online learning; second, the lack of skills in using technology for learning purposes; and third, the limitations of online learning support facilities. Teachers' perception of online learning is an important factor influencing teachers' behavior and online learning interpretation. Teachers' perception of the online learning process is divided into two aspects: the level of efficiency and learning effectiveness.

Online learning efficiency means comparing the quality level of online learning with the cost, the time required, and learning tasks. Learning quality is defined as learning outcomes under learning achievement standards. At the same time, costs are understood as the number of funds spent on the learning process. Time is defined as the length of time it takes to learn. Learning load is defined as learning tasks completed by students and teaching preparation by the teacher (Table 2).

Table 2. Teacher Perception of Online Learning Efficiency

\begin{tabular}{ccc}
\hline Efficiency & Perception & Percentage \\
\hline Cost & Very Expensive & 9 \\
& Expensive & 68 \\
& Regular Fees & 18 \\
& Inexpensive & 5 \\
\multirow{2}{*}{ Time consumption } & Long time & 77 \\
& On Schedule & 23 \\
& Short time & 0 \\
Student workload & Heaviness & 64 \\
& Ordinary & 27 \\
& Slight & 9 \\
\hline
\end{tabular}


In terms of cost (diagram 1), participants perceived the cost of online learning as prohibitive $(9 \%)$ because it is unaffordable and requires financial support to meet it. Participants assume that online learning is expensive, meaning they can meet but hard to fulfill. While $18 \%$ of participants stated that online learning costs can still be affordable, and the rest $(5 \%)$ very affordable.

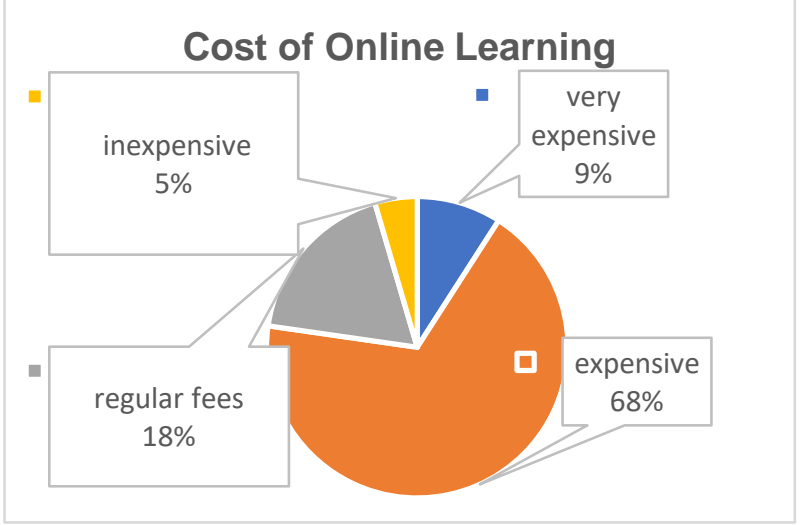

Figure 1. Teacher Perception of Online Learning Cost

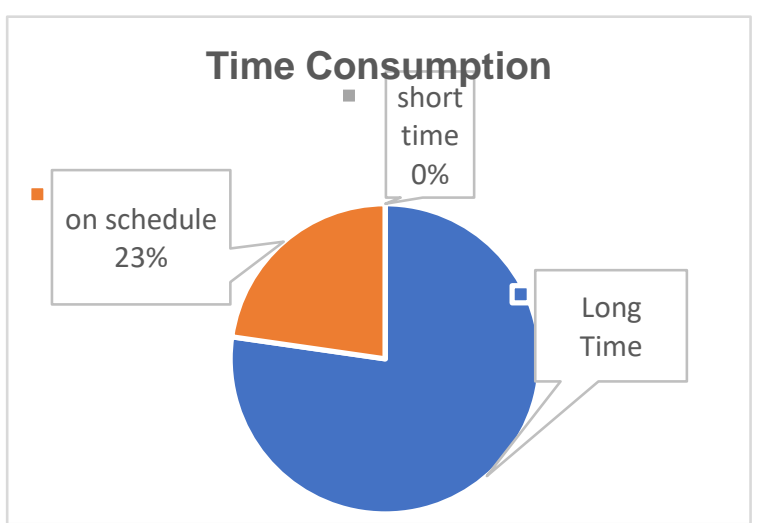

Figure 2. Teacher Perception of Online Learning Time Consumption

Regarding the time required, the teacher's perception of online learning efficiency shows that $77 \%$ of participants rated online learning as taking a long time. $23 \%$ of participants rated the time needed according to a predetermined schedule, no participant $(0 \%)$ stated that the time required for online learning was short. Furthermore, Teachers' perception of The students' work showed that Participants argued that students had more difficult online learning tasks than offline learning (64\%). In comparison, $23 \%$ of participants expressed students' burden in ordinary online learning, such as offline learning. As many as $9 \%$ of participants said students' light learning burden during online learning. The data collected showed that most participants have a perception that online learning is inefficient.

Related online learning effectiveness is understood as achieving learning objectives during online learning at home. In this aspect, $45 \%$ of participants thought that learning objectives did not complete in online learning. $32 \%$ of participants stated that learning goals were achieved, and the remaining $23 \%$ achieved enough.

The online learning system implemented during the pandemic causes students to have difficulty understanding learning materials. As a result, students did not achieve learning objectives. One of the participants (8) stated;

"... In terms of learning outcomes, online learning does not achieve learning objectives. After the evaluation of learning, many children do not understand the learning materials."

Based on the data presented, the researcher concluded that the average teacher in this study perceived online learning during the pandemic period to be less efficient and effective.

The second factor is teachers' ability to develop and apply technology in online learning during the pandemic. Although the skills of using learning technology are a necessity today, there are still many elementary school teachers who do not care about these skills. Teachers feel enough with the media and teaching materials that they already have. The offline learning process has also not required them to have the skills to use technology in learning. As expressed by the participants (17);

"... all this time, I am used to offline learning. So never use online media, social media, or other online learning resources. Therefore, I find it difficult to teach online during the pandemic." 
While the school considers teachers' mastery of online learning technology as not very important because the existing learning model is enough. As a result, schools less facilitate teachers to train or conduct training in developing and using online learning technology. For example, a statement from a teacher;

"... Before the Covid-19 pandemic, I had never attended online learning training. The school also never held online learning training because I felt that I had used enough existing learning methods. Finally, now I am confused about carrying out online learning."

Another fact related to online learning technology mastery is that teachers who have received online learning training do not always apply training results in learning. So the skills that have been gained do not develop and tend to weaken, even disappear. As acknowledged by the two participants (1) and (3):

"... the principal has assigned me to take online learning training. However, I gained from the training was not applied, so long ago forgot..." (1). "I have attended online learning training, but I have never practiced in class. In my opinion, it is impractical, let alone the school facilities do not support" (3)

The conclusion from the interviews with participants concluded that teachers feel that they have taught enough using conventional media and teaching methods to weaken mastery and utilization of technology for learning.

The third factor, online learning, requires some equipment such as laptops, handphones, and internet networks. During the Covid pandemic, technology products become a basic necessity in the learning process, so they must be available in schools and owned by teachers if the learning process is in their own homes. However, the actual condition of many teachers is challenging to complete the tools. The price of laptops and handphones are relatively expensive not always reachable by all teachers. Similarly, data packages are costly enough to be used to carry out learning. The same is true for many students' parents who do not have enough funds to provide laptops or handphones worth using online.

Based on the interviews with teachers, pointing out the facts, one of the main problems of online learning is the limited internet access and online learning equipment. Many teachers who have laptops or handphones are not compatible, so it is impossible to deliver educational activities online. This condition affects teachers who are not maximal and psychologically cause feelings of anxiety and distrust in teaching online. Citing some participants statements on less supportive learning facilities. Of the three factors triggering low self-efficacy teachers carry out online learning during the pandemic period, it appears that teachers' perception and competence need to be the main concern for improving teacher self-efficacy.

\section{Discussion}

This study explains three factors that affect a teacher's low self-efficacy levels. First, it is related to the teacher's perception of online learning's efficiency and effectiveness during the covid-19 period, which requires more significant time and costs and a heavier learning burden for both teachers and students. While the purpose of learning with the system online is less achieved. Second, in pedagogy, teachers have a low level of mastery and technology application skills for learning. It can influence the performance of teachers in teaching. Third, the online learning support system is minimal, including online learning equipment facilities such as a decent laptop or mobile phone and an accessible internet network. These factors can determine teachers' level of confidence in themselves to carry out online learning during the pandemic covid-19.

This study indicates that elementary school teachers' level of self-efficacy in implementing online learning in the Covid-19 pandemic is divided into internal and external 
dimensions. The internal dimension relates to how teachers view online learning. Most teachers think that online teaching is less efficient and effective. Online learning experiences that fail to achieve the previously expected goals can form teachers' perceptions (Fitriyani et al., 2020; Indrawati et al., 2020). The teacher unpreparedness to teach online causes teachers to have a wrong perception of online learning (Abidah et al., 2020; Rasmitadila et al., 2020).

In addition to internal factors, the study also found external factors. In addition to internal factors, the study also found that primary school teachers with low self-efficacy are also inseparable from the online learning system's lack of support. The high price of online learning equipment (laptops, mobile phones, expensive internet quotas) has influenced teachers' motivation to learn online. The difficulty or lack of smooth internet access allows teachers to have an unsatisfactory experience teaching online (Hampton et al., 2020; Türkoğlu et al., 2017). Satisfaction in teaching is associated with high self-efficacy (Horvitz et al., 2015; Wyatt, 2014).

The success of online learning during the covid-19 pandemic is highly dependent on teacher involvement realized by the motivation and self-efficacy of teachers carrying out online learning. However, empirically, many primary school teachers have low self-efficacy towards online learning. Based on this result, the condition prompted the formulation of three action plans. Namely, first, the improvement of teacher pedagogy competencies, especially the mastery of technology and its application in online learning. Such improvements can be in the form of training or workshops. Otherwise, failure to master certain behaviors can decrease self-efficacy. Second, the government and schools improved online learning support systems, both in the procurement of online learning equipment and internet access. Third, increase emotional, social support and appreciation to elementary school teachers to be motivated in carrying out online learning. In the online learning context in the current pandemic, the second and third action plans urgently carried out as a source for the development of self-efficacy teachers in teaching online as delivered that social support and prosperous psychological conditions in achieving the goal can stimulate self-efficacy (Kayabınar et al., 2021; Lazarides \& Warner, 2020). These three action plans can be a foundation for schools, communities, and governments in maintaining the quality of online learning based on teachers' and students' well-being.

Teachers' perspective in reviewing the success of education during Covid-19 opens a broader and holistic understanding of the concept of learning-oriented towards teachers and students' welfare. As an indicator of the quality of teacher personality and teacher welfare, self-efficacy often does not get attention for the policy of improving the quality of education. Whereas the teacher's belief in his ability influences the way teachers think, feel, and behave in teaching and determining the quality of learning. This research pays great attention to teachers' personal quality becomes the starting point for improving Indonesia's quality of education that prospers teachers.

\section{Conclusions and Suggestions}

In that context of self-efficacy, teachers become the key to online learning success in the pandemic. Teachers' low self-efficacy to face limitations and all learning problems will impact the quiet intensity and quality of teacher involvement in the online learning process. Efforts to improve teacher self-efficacy means paying attention to three things: the positive perception of teachers towards online learning, improving the pedagogy competency of online learning, and supporting an adequate education system in the pandemic.

\section{References}

Abidah, A., Hidaayatullaah, H. N., Simamora, R. M., Fehabutar, D., \& Mutakinati, L. (2020). The Impact of Covid-19 to Indonesian Education and Its Relation to the Philosophy of "Merdeka Belajar." Studies in Philosophy of Science and Education, 1(1), 38-49. https://doi.org/10.46627/sipose.v1i1.9. 
Achurra, C. (2012). Teacher' Self-Efficacy And Student Learning. The European Journal of Social \& Behavioural Sciences, 2(2), 366-383. https://doi.org/10.15405/futureacademy/ejsbs(2301-2218).2012.2.17.

Alibakhshi, G., Nikdel, F., \& Labbafi, A. (2020). Exploring the consequences of teachers' selfefficacy: a case of teachers of English as a foreign language. Asian-Pacific Journal of Second and Foreign Language Education, 5(1). https://doi.org/10.1186/s40862-02000102-1.

Amin, I., Yousaf, A., Walia, S., \& Bashir, M. (2021). What Shapes E-Learning Effectiveness among Tourism Education Students? An Empirical Assessment during COVID19. Journal of Hospitality, Leisure, Sport and Tourism Education, xxx(xxxx), 100337. https://doi.org/10.1016/j.jhlste.2021.100337.

Baber, H. (2020). Determinants of Students 'Perceived Learning Outcome and Satisfaction in Online Learning during the Pandemic of COVID19. Journal of Education and ELearning Research, 7(3), 285-292. https://doi.org/10.20448/journal.509.2020.73.285.292.

Berga, K. A., Vadnais, E., Nelson, J., Johnston, S., Buro, K., Hu, R., \& Olaiya, B. (2021). Blended learning versus face-to-face learning in an undergraduate nursing health assessment course: A quasi-experimental study. Nurse Education Today, 96(October 2020), 104622. https://doi.org/10.1016/j.nedt.2020.104622.

Cardullo, V., Wang, C., Burton, M., \& Dong, J. (2021). K-12 teachers' remote teaching selfefficacy during the pandemic. Journal of Research in Innovative Teaching \& Learning, 14(1), 32-45. https://doi.org/10.1108/jrit-10-2020-0055.

Clayson, D., \& Sheffet, M. (2012). The Impact of Teacher Self-efficacy on the Students' Motivation and Achievement. Theory and Practice in Language Studies, 2(3), 483491. https://doi.org/10.4304/tpls.2.3.483-491.

Cornelia, E., Van Rooij, M., Fokkens-Bruinsma, M., \& Goedhart, M. (2019). Preparing Science Undergraduates for a Teaching Career: Sources of Their Teacher SelfEfficacy. Marjon Fokkens-Bruinsma \& Martin Goedhart, 54(3), 270-294. https://doi.org/10.1080/08878730.2019.1606374.

Corry, M., \& Stella, J. (2018). Teacher self-efficacy in online education: a review of the literature. Research in Learning Technology, 26. https://doi.org/10.25304/rlt.v26.2047.

Dhawan, S. (2020). Online Learning: A Panacea in the Time of COVID-19 Crisis. Journal of Educational Technology Systems, 49(1), 5-22. https://doi.org/10.1177/0047239520934018.

El Refae, G. A., Kaba, A., \& Eletter, S. (2021). Distance learning during COVID-19 pandemic: satisfaction, opportunities and challenges as perceived by faculty members and students. Interactive Technology and Smart Education, ahead-ofp(ahead-of-print). https://doi.org/10.1108/ITSE-08-2020-0128.

Fauzi, I., \& Sastra Khusuma, I. H. (2020). Teachers' Elementary School in Online Learning of COVID-19 Pandemic Conditions. Jurnal Iqra': Kajian IImu Pendidikan, 5(1), 58-70. https://doi.org/10.25217/ji.v5i1.914.

Fitriyani, Y., Fauzi, I., \& Sari, M. Z. (2020). Motivasi Belajar Mahasiswa Pada Pembelajaran Daring Selama Pandemik Covid-19. Profesi Pendidikan Dasar, 7(1), 121-132. https://doi.org/10.23917/ppd.v7i1.10973.

Hampton, D., Culp-Roche, A., Hensley, A., Wilson, J., Otts, J. A., Thaxton-Wiggins, A., Fruh, S., \& Moser, D. K. (2020). Self-efficacy and Satisfaction With Teaching in Online Courses. Nurse Educator, 302-306. https://doi.org/10.1097/NNE.0000000000000805.

Haverback, H. R. (2020). Middle Level Teachers Quarantine, Teach, and Increase SelfEfficacy Beliefs: Using Theory to Build Practice During COVID-19. In Middle Grades Review (Vol. 6, Issue https://scholarworks.uvm.edu/cgi/viewcontent.cgi?article=1167\&context=mgreview.

Hensley, L. C. (2014). Reconsidering active procrastination: Relations to motivation and achievement in college anatomy. Learning and Individual Differences, 36, 157-164. https://doi.org/10.1016/j.lindif.2014.10.012. 
Hong, E., Mason, E., Peng, Y., \& Lee, N. (2015). Effects of homework motivation and worry anxiety on homework achievement in mathematics and English. Educational Research and Evaluation, 21(7-8), 491-514. https://doi.org/10.1080/13803611.2015.1131721.

Horvitz, B. S., Beach, A. L., Anderson, M. L., \& Xia, J. (2015). Examination of Faculty Selfefficacy Related to Online Teaching. Innovative Higher Education, 40(4), 305-316. https://doi.org/10.1007/s10755-014-9316-1.

Indrawati, M., Prihadi, C., \& Siantoro, A. (2020). The Covid-19 Pandemic Impact on Children's Education in Disadvantaged and Rural Area Across Indonesia. International Journal of Education (IJE), 8(4), 19-33. https://doi.org/10.5121/ije.2020.8403.

Joshi, A., Vinay, M., \& Bhaskar, P. (2020). Impact of coronavirus pandemic on the Indian education sector: perspectives of teachers on online teaching and assessments. Interactive Technology and Smart Education, ahead-of-p(ahead-of-print). https://doi.org/10.1108/ITSE-06-2020-0087.

Karasmanaki, E., \& Tsantopoulos, G. (2021). Impacts of social distancing during COVID-19 pandemic on the daily life of forestry students. Children and Youth Services Review, 120(December 2020), 105781. https://doi.org/10.1016/j.childyouth.2020.105781.

Kayabınar, E., Kayabınar, B., Önal, B., Zengin, H. Y., \& Köse, N. (2021). The musculoskeletal problems and psychosocial status of teachers giving online education during the COVID-19 pandemic and preventive telerehabilitation for musculoskeletal problems. Work, 68(1), 33-43. https://doi.org/10.3233/WOR-203357.

Lazarides, R., \& Warner, L. M. (2020). Teacher Self-Efficacy. Oxford Research Encyclopedia of Education, 1-22. https://doi.org/10.1093/acrefore/9780190264093.013.890.

Lazarides, R., Warner, L. M., Lazarides, R., \& Warner, L. M. (2020). Teacher Self-Efficacy. In Oxford Research Encyclopedia of Education. Oxford University Press. https://doi.org/10.1093/acrefore/9780190264093.013.890.

Liao, S., Hong, J.-C., Wen, M.-H., Pan, Y.-C., \& Wu, Y.-. (2018). Applying Technology Acceptance Model (TAM) to explore Users' Behavioral Intention to Adopt a Performance Assessment System for E-book Production. EURASIA Journal of Mathematics, Science and Technology Education, 14(10). https://doi.org/10.29333/ejmste/93575.

Ma, J., Han, X., Yang, J., \& Cheng, J. (2015). Examining the necessary condition for engagement in an online learning environment based on learning analytics approach: The role of the instructor. Internet and Higher Education, 24, 26-34. https://doi.org/10.1016/j.iheduc.2014.09.005.

Mardiana, H. (2020). Lecturers' Adaptability To Technological Change And Its Impact On The Teaching Process. JPI, 9(2). https://doi.org/10.23887/jpi-undiksha.v9i2.24595.

Marsh, H. W., Pekrun, R., Parker, P. D., Murayama, K., Guo, J., Dicke, T., \& Arens, A. K. (2019). The murky distinction between self-concept and self-efficacy: Beware of lurking jingle-jangle fallacies. Journal of Educational Psychology, 111(2), 331-353. https://doi.org/10.1037/edu0000281.

Moè, A., Pazzaglia, F., \& Ronconi, L. (2010). When being able is not enough. The combined value of positive affect and self-efficacy for job satisfaction in teaching. Teaching and Teacher Education, 26(5), 1145-1153. https://doi.org/10.1016/j.tate.2010.02.010.

Putri, F. A. R., \& Fakhruddiana, F. (2019). Self-efficacy Guru Kelas dalam Membimbing Siswa Slow Learner. JPK (Jurnal Pendidikan Khusus), 14(1), 1-8. https://doi.org/10.21831/jpk.v14i1.25161.

Rachmadtullah, R., \& Samsudin, A. (2020). The Perceptions of Primary School Teachers of Online Learning during the COVID-19 Pandemic Period: A Case Study in Indonesia. https://doi.org/10.29333/ejecs/388.

Rasmitadila, Aliyyah, R. R., Rachmadtullah, R., Samsudin, A., Syaodih, E., Nurtanto, M., \& Tambunan, A. R. S. (2020). The Perceptions of Primary School Teachers of Online Learning during the COVID-19 Pandemic Period: A Case Study in Indonesia. Journal of Ethnic and Cultural Studies, 7(2), 90-109. 
https://doi.org/http://dx.doi.org/10.29333/ejecs/388.

Richardson, J. C., \& Newby, T. (2010). American Journal of Distance Education The Role of Students' Cognitive Engagement in Online Learning. Taylor \& Francis, 21(1), 23-37. https://doi.org/10.1207/s15389286ajde2001_3.

Sa'pang, A. W., \& Purbojo, R. (2020). Teacher's self-efficacy, understanding of students characters, and understanding of the 21st century skills as predictors of facilitator type of teaching style. Jurnal Psikologi Ulayat: Indonesian Journal of Indigenous Psychology, 7(2), 192-211. https://doi.org/10.24854/JPU108.

Santi, E. A., Gorghiu, G., \& Pribeanu, C. (2020). Teachers' Perceived Self-Efficacy Concerning the Use of Mobile Technology in Education, Considering the "Working from Home" Format. Revista Romaneasca Pentru Educatie Multidimensionala, 12(1Sup2), 157-166. https://doi.org/10.18662/rrem/12.1sup2/259.

Sharma, L., \& Srivastava, M. (2020). Teachers' motivation to adopt technology in higher education. Journal of Applied Research in Higher Education, 12(4), 673-692. https://doi.org/10.1108/JARHE-07-2018-0156.

Singh, V., \& Thurman, A. (2019). How Many Ways Can We Define Online Learning? A Systematic Literature Review of Definitions of Online Learning. American Journal of Distance Education, 33(4), 289-306. https://doi.org/10.1080/08923647.2019.1663082.

Skaalvik, E. M., \& Skaalvik, S. (2010). Teacher Self-efficacy and Teacher Burnout: A Study of Relations. Teaching and Teacher Education, 26(4), 1059-1069. https://doi.org/10.1016/j.tate.2009.11.001.

Sökmen, Y. (2021). The role of self-efficacy in the relationship between the learning environment and student engagement. Educational Studies, 47(1), 19-37. https://doi.org/10.1080/03055698.2019.1665986.

Türkoğlu, M. E., Cansoy, R., \& Parlar, H. (2017). Examining relationship between teachers' self-efficacy and job satisfaction. Universal Journal of Educational Research, 5(5), 765-772. https://doi.org/10.13189/ujer.2017.050509.

Tzioti, M.-C., Mantelou, E., Degleris, N. E., Solias, A., Karamberi, M., \& Romanou, N. (2010). Job burnout and self-efficacy survey among elementary school teachers in Greece. Annals of General Psychiatry, 9(S1), 1-1. https://doi.org/10.1186/1744-859x-9-s1s192.

Uzunboylu, H., \& Ozdamli, F. (2011). Teacher perception for m-learning: scale development and teachers' perceptions. Journal of Computer Assisted Learning, 27(6), 544-556. https://doi.org/10.1111/j.1365-2729.2011.00415.x.

Wang, P.-H., Wu, P.-L., Yu, K.-W., \& Lin, Y.-X. (2015). Influence of Implementing Inquirybased Instruction on Science Learning Motivation and Interest: A Perspective of Comparison. Procedia - Social and Behavioral Sciences, 174, 1292-1299. https://doi.org/10.1016/j.sbspro.2015.01.750.

Wargadinata, W., Maimunah, I., Dewi, E., \& Rofiq, Z. (2020). Student's Responses on Learning in the Early COVID-19 Pandemic. Tadris: Jurnal Keguruan Dan IImu Tarbiyah, 5(1), 141-153. https://doi.org/10.24042/tadris.v5i1.6153.

Wyatt, M. (2014). Towards a re-conceptualization of teachers' self-efficacy beliefs: tackling enduring problems with the quantitative research and moving on. International Journal of Research and Method in Education, 37(2), 166-189. https://doi.org/10.1080/1743727X.2012.742050.

Yang, X., Zhang, M., Kong, L., Wang, Q., \& Hong, J. C. (2020). The Effects of Scientific Selfefficacy and Cognitive Anxiety on Science Engagement with the "QuestionObservation-Doing-Explanation" Model during School Disruption in COVID-19 Pandemic. Journal of Science Education and Technology. https://doi.org/10.1007/s10956-020-09877-x.

Zee, M., \& Koomen, H. M. Y. (2016). Teacher Self-Efficacy and Its Effects on Classroom Processes, Student Academic Adjustment, and Teacher Well-Being. Review of Educational Research, 86(4), 981-1015. https://doi.org/10.3102/0034654315626801. 